\title{
Cooperation Between Migrant Parents and Teachers in School: A Resource?
}

\author{
MARTHA LEA ${ }^{1}$
}

$\approx$ Even smaller Western countries receive immigrants from remote areas with poorer living conditions. As stated in the U.N. Child Convention, immigrant children should be given equal opportunities in education. Parents are always interested in their children's future, and education may gain from stronger cooperation between school and parents. Some research shows that even illiterate parents may support their children's training in a second language (Cummins, 1986/2001, p. 665). Dialogues between teachers and parents promote mutual understanding and increase parents' knowledge of school and society. This might make the parents trust society more, enhance their acculturation and reduce future intergenerational conflicts (Portes \& Rumbaut, 2001). A professional teacher needs cultural knowledge and understanding in order to give her/his students an education adapted to their needs. Migrant students especially should feel that there is coherence in their education, because cultural conflicts sap their energy and may also cause identity problems and lead to lack of motivation. For teachers it is important that education policy provides for equal opportunities. Norway has an inclusive policy concerning immigrant children. The students have language support to a certain degree both in their mother tongue and in Norwegian when needed. Parents and schools are obliged to cooperate in education, and some support is therefore given to translation. Cooperation is required by conferences and meetings. There are gains for all parties in cooperation between school and migrant parents, but it is difficult to develop mutual cultural understanding for all students and equal opportunities for migrant students. This requires a clear school policy, the means to implement it, and teacher competence. It takes a process to learn how to cooperate and give adequate support. The Norwegian policy shows a will to cooperation, but the implementation of the policy can still be improved.

Keywords: Cooperation school/migrant parents, Dialogue teacher/parents, Multicultural schools, School policy for migrant students

1 University in Stavanger

martha.lea@uis.no 


\title{
Sodelovanje med starši migranti in učitelji
}

\author{
Martha LeA
}

$\propto$ Celo majhne zahodne države sprejemajo priseljence iz oddaljenih držav z revnejšimi življenjskimi pogoji. Kot je zapisano tudi v Konvenciji o otrokovih pravicah, želimo otrokom priseljencem omogočiti enake možnosti za izobraževanje. Starše vedno zanima prihodnost njihovih otrok; izobraževanje pridobi na kakovosti, če je sodelovanje med šolo in starši trdno. Raziskave kažejo, da lahko celo nepismeni starši podpirajo otroke pri urjenju drugega jezika (J. Cummins, 1986/2001, str. 665). Dialog med učitelji in starši spodbuja medsebojno razumevanje ter povečuje poznavanje šole in družbe s strani staršev. Posledično bodo mogoče starši bolj zaupali družbi, izboljšali svojo akulturacijo in zmanjšali prihodnje medgeneracijske konflikte (Portes \& Rumbaut, 2001). Profesionalni učitelj mora poznati in razumeti kulturo učenca, da bi mu lahko nudil prilagojeno izobraževanje. Še posebno učenci migranti bi morali občutiti skladnost $\mathrm{v}$ izobraževanju, saj jim kulturni konflikti jemljejo energijo, povzročijo težave $\mathrm{z}$ identiteto in vodijo $\mathrm{v}$ pomanjkanje motivacije.

Za učitelje je pomembno, da izobraževalna politika omogoča enake možnosti. Norveška ima uveljavljeno inkluzivno politiko za otroke priseljence. Učencem se nudi pomoč do določene mere pri usvajanju jezi$\mathrm{ka}$ - maternega in norveškega, če je potrebno. Sodelovanje med šolo in starši je obvezno, zato je omogočeno tudi prevajanje. Sodelovanje poteka pri konferencah in sestankih.

$\mathrm{V}$ procesu sodelovanja pridobita obe strani - šola in starši migranti -, vendar je težko vzpostaviti medsebojno kulturno razumevanje za vse učence in enake možnosti za učence migrante. To zahteva jasno šolsko politiko, sredstva za izvajanje in ustrezne učiteljeve kompetence. Učenje sodelovanja in nudenja primerne pomoči je proces. Norveška politika kaže voljo za sodelovanje, vendar so pri izvajanju politike še mogoče izboljšave.

Ključne besede: sodelovanje šola - starši migranti, multikulturne šole, dialog učitelji - starši, politika šole glede učencev migrantov 


\section{Introduction}

The aim of the education system has always been to give every generation possibilities to develop their competence for a social life. Migrant families bring with them various school experiences, and encounter different educational practices and knowledge that cause discontinuity in the education of the children. This might result in a poorer basis for development in a new society. Nowadays, we discuss the importance of language competence, how to meet cultural differences or secure socioeconomic status, and how to give migrant children equal opportunities. There has always been contact between schools and parents through parent-teacher meetings, or especially when students have problems. Kindergarten teachers meet parents bringing their children every day, and they can have a small talk when needed. The last immigration wave in Norway started in the years after 1970 and has increased gradually, especially the previous ten years (Brochmann \& Kjelstadli, 2008). The official obligation to cooperate was stated in the Education Act and Regulations by the Ministry of Education and Research (2005). Some goals were presented by the same ministry in the 'Strategic Plan. Equal education in practice, (2004-2009)' (hereinafter: 'Strategic Plan').

Currently, all municipalities in Norway have immigrants and the responsibility to provide equal education opportunities to majority and minority children. Migrant parents often struggle with their own challenges related to language, culture, economy, and also some fears of a new and different society. The Pisa studies show lower school results for migrant students (Pisa 2009 results: Vol. II OECD, 2010, p.65 ff). The official policy targets the significance of cooperation between parents and, not least, immigrant parents in schools. To be more conscious about prerequisites for cooperation and improved results for migrant students should be possible. Therefore, the following questions will be addressed here:

1. Why should schools cooperate with migrant parents?

2. What are the possibilities and challenges in official Norwegian policy?

3. What are teachers' experiences?

To obtain answers to the questions, it is necessary to examine research literature about migrants' situation and education experiences. Knowledge about immigrants' education processes and consequences for schools, students and families might give support to the way forward. The Norwegian policy regarding the education for migrant students is found in the Education Act and Regulations (2005) and different framework documents. The present situation has to be seen in the light of desired goals for future perspectives. 
The sources might give interdisciplinary answers and elements relevant in different degree to the three questions.

\section{Why should schools cooperate with migrant parents?}

\section{The general situation}

To what extent is the Pisa test of the OECD relevant for defining necessary qualifications in the life in European society? It tests the students' knowledge and skills in using the knowledge in the three subjects (language, science and mathematics) considered to be necessary for the future of Western society. The Pisa test results show lower scores by first and second generation migrant students than by those of majority students (Pisa 2009 results: Vol. II OECD, 2010). Skills such as social competence, creativity or tolerance are not tested. The aims of the 1989 UN Child Convention serve as a guard to securing fair treatment for all children, giving them equal education possibilities, and developing mutual cultural respect in school and society. It seems as the aims of the Pisa tests compared to the aims of equal possibilities and mutual cultural respect could lead to different education programs. This question must be dealt with elsewhere.

The Norwegian Framework Plan for elementary education, 'Kunnskapsløftet' (Knowledge Promotion), combines the aspects of knowledge and cultural education by maintaining that 'teachers and instructors also have to have multicultural competence and knowledge about diverse starting points and strategies of learning among students' (Knowledge Promotion, 2008, p. 5). Different aspects of Norway's official policy, to which I will return, might give limitations and possibilities in questions of education.

Knowledge Promotion defines equality as students, regardless of gender, age, language etc., having equal opportunities to develop their competence in an inclusive environment (ibid., 2008). Comparing the aim of equal education for all with minority children's significantly lower result in the Pisa test, we see that most likely there are factors in the education of this group that a receiving country has to improve to secure equality. Teachers and parents share responsibilities for mutual cooperation, which is important to create good conditions for learning according to Knowledge Promotion (ibid, 2008, p. 5). The socioeconomic situation has to be solved outside school.

Jim Cummins' article 'Empowering minority students: A framework for Intervention' (1986) was republished 15 years later in the same journal, Herald Education Review (HER, (1986/2001); the reprinting showed its relevance. In Cummins' thinking about the necessity of cooperation between parents and 
school, he uses the concept of power. Parents, teachers and students have power; teachers are formally responsible for the education at school, and parents are at home. Students have the resources and drive to develop both identity and capacity. There is mutual dynamism and one might say they 'work in the same field'. Interpretations of intentions and aims expressed in official documents might vary. Therefore, cooperation between school and parents is of importance in secure coherence in education and avoiding discrepancies. According to the Child Convention, the aim of education for all is to develop the students' personality, which includes respect for the language, the parents, cultural identity and values of one's own and other countries (U.N. Child Convention, 1989, $\$ 29$ ). Therefore, coherence in education seems to be in accordance with the aim of the convention. Since language and culture questions are especially important elements in the migrant children's family and school situation, I have chosen culture and language as main areas to investigate.

\section{Cooperation in questions of culture}

Culture includes traditions, social rules, values, and the way of life. Even if culture is regarded as being the 'glue' of a society, its elements are not static. Acquired cultural values become included in personal identity. Immigrant students will be in the process of developing their own identity and have to find their own way between their parents' cultural values, the values of the new country presented at school and the special culture of the students (Cummins, 1986/2001). Migrant parents want their children to become well educated for the future prosperity in a new society (Sjögren, 2000). Traditionally, for the many of the migrant families Sjögren interviewed, the teacher was regarded as having all necessary knowledge, which students learnt by repetition (ibid, 2000, p. 15). Repeated knowledge might be part of the qualifications the Pisa tests represent, but competence to use the knowledge in a relevant way is also required. Thus, there might be differences between parents and the school regarding what kind of knowledge is appreciated.

At the same time, migrant parents are sceptical of some other values in their new country, especially of religious questions regarding values being part of their identity and culture (Barry, 2001). These processes to acquire and develop their own identity have many facets. Even in a majority culture, there are tendencies to reject some or include other influences; this pulls people in different directions. This dynamism, which we may call 'acculturation', is found in both national and minority cultures. The process of acculturation is a special challenge for migrant groups. However open the new country and majority are, a minority will always live in an identity challenge and have less power than 
the majority (Cummins, 1986/2001; Nieto, 2010; Parekh, Robins 2003; 2008; Simon; 2004).

Cummins calls this 'a process of negotiating identities' (1986/2001, p. 653 ). This is an on-going process for students in school and in the family. Parekh indicated the importance of feeling welcome (Parekh, 2008, p. 87). Simon said it is important to acknowledge the culture, language and also the creative and intellectual resources that students bring with them (Simon, 2004). In other words, the teacher has to care about this openness, and be aware of, include, develop and present the students' resources. The openness to impulses from other cultures is necessary, Robins stated. Without openness, the culture will become only the past (Robins, 2003). To do this in a balanced way, teachers need to be well acquainted with the students and their cultural background, but parents also have to be aware of which differences the school represents to accept the way forward for their children in the new world.

The meaning of respect might, for example, be necessary to clarify for immigrant parents in Nordic countries. Annick Sjögren writes about differences between Swedish teachers' opinions and parents' approach from foreign, more authoritarian cultures (Sjögren, 2000). The teachers from a more egalitarian society thought that respect between student and teachers had to be based on personal integrity and equality rather than on an authoritarian hierarchy where age or social status counted. As personal identity often is rooted in cultural identity, questions about cultural differences, especially religious values, cause strong feelings (Barry, 2001, p. 33). The discussion about the hijab as a Muslim code for clothing is well known from many countries. In France, it became the subject of a troublesome national discussion. For teachers, parents and students, mutual respect in discussions and information situations is essential.

Without this dialogue and mutual understanding between school and parents, cooperation may be difficult, and possibly end in intergenerational family conflicts about traditions and values. Conflicts of different kinds take energy. In their research, Portes et al. registered a special drive for education in immigrant students at the beginning of their attendance at school. Dissonant acculturation, poor schools and weak families could make students 'abandon their educational goals as "unattainable dreams", which means a slower drive and less learning activities' (Portes \& Rumbaut, 2001, p. 268).

Coherence in the education of students gives security. In my interviews in Norwegian schools, a teacher in one school and a director in another indicated the positive reactions they registered in the students when they could say that 'I met your parents yesterday', 'Your mother was at our meeting; she saw your classroom' or 'On my holiday, I visited your country [...], and look, I 
brought a book in your language from the trip. 'The children were smiling (Lea, 2007,2009 ). This is an inclusive way of saying 'I see you, know your mother and know where you come from'. It also emphasises the informal possibilities of creating an open atmosphere, like in kindergartens where the teacher meets one of the parents every day. This clarification of, and openness to cultural differences in school are important to ease the processes of acculturation and identity development for both students and parents, also for the majority.

\section{Cooperation in language learning}

Language is a vital part of culture, the communication, identity building and consequently in education. There have been heated discussions about methods of language learning. Those who want a one-way assimilation into the majority's system have believed in the forced use of the majority language both for students and also in the family. Cummins refers to a British project, the Haringey project, where illiterate parents without competence in English agreed to listen to their children's reading on a regular basis. This group was compared with another group with some extra teaching support by a specialist. The progress was significantly greater in the group reading to the parents than the group getting support from specialists. The teachers also reported progress in the students' increased learning and better behaviour (Cummins, 1986/2001). This showed that even illiterate parents could support their children's language learning. Sonia Nieto refers to research of second language competence in immigrant students living in families where their mother tongue is practiced. This showed that the bilingual additive practice improved the language competence. Suppressed native language at home did not. Her conclusion was: 'This research confirms that simply speaking English is no guarantee that academic success will follow. [...] (But) when children are able to keep up with their native language at home, they develop meta-linguistic awareness, i.e. a greater understanding of how language itself works, and to use language for further learning' (Nieto, 2010, p. 147).

Portes and Rumbaut wrote: 'Early parent-child conflict and limited bilingualism reduce ambition [...] the pattern is confirmed with the opposite effect of fluent bilingualism' (2001, p. 227). This shows the importance of using the mother tongue in second language learning.

It is one thing is to understand the use of words and sentences in everyday speech; another is to understand a concept. An ordinary Norwegian activity for a class is to make 'a trip to a cottage'. Immigrant parents as well as students might be afraid of what kind of activity this includes. This understanding develops through experience, explanations and communication. Therefore, the 
general information to parents about activities at school and possibly inclusion in them supports their understanding of school life in a new society, and promises a secure life for their children.

Another linguistic aspect is the difference between everyday language and the language as tool for thinking. Anne Høigård referred to a Swedish researcher, Kenneth Hyltenstam, who has found that it takes five to seven years to develop a second language for thinking and learning in school even with fluent every-day language. This development needs systematic language support for years (2006, p. 191).

\section{Where cooperation does not function}

One of the signs showing that cooperation does not function might be when students drop out of school. We know that the education for Roma children often is characterised as disruptive in several countries. This does not need to be so. In a Pestalozzi conference in Slovenia (2011), a director in a Slovenian school in Maribor reported positive cooperation with Roma parents and that the Roma students stayed in school. ${ }^{2}$

In a final research paper, I discussed the situation of Cape Verde students in Portugal trying to pass nine years of obligatory school, but where the drop-out percentage is high (Lea, 2008). The situation is described in an article (Ferreira \& Cardoso, 2004). The reasons the students give for dropping out of school are partly problems with disruptive behaviour meeting educational norms unfamiliar to them and failing in school. They are discriminated against by peers and adults, including teachers. The school content does not seem relevant for their expected future, according to the drop-outs. Their understanding of the Portuguese language is insufficient in education, as their mother tongue is more or less a Creole language. All teaching is in Portuguese, although the Portuguese Education Law No 6, Article 8, from the Ministry of Education (2001) says that the schools must provide special activities for students with Portuguese as a second language. The conclusion of the Portuguese researchers is that teachers neither respect these students' language, nor their culture, and they have the stereotypical idea of their families as being dysfunctional. They express this directly in the article: '[...] teachers have low expectation about these children and reduce their chances of being successful at school' (Ferreira \& Cardoso, 2004, p. 82; Lea, 2008).

I visited a slum area in Lisbon where Cape Verde families had been

2 Pestalozzi Workshop with the topic: 'Intercultural education for everyday practice: Pedagogical illusion or practicable reality?' Ljubljana, April, 2011. 
living for years. Some Portuguese young people gave voluntary support in different ways. For example, one young migrant boy had built his own computer as result of this voluntary assistance. The voluntary support seems to meet them more on their own turf. The dropout examples show catastrophic results for students when the school does not respect the students' language, background or their parents. The education becomes irrelevant for the students. Thus far, I have not found research about the effects of voluntary contributions.

\section{Cooperation, a win-win situation for all parts}

Through the research, we have seen that the mother tongue is valuable in learning a second language. Even illiterate parents' support of their children in their second language learning is valuable. Conflicts between school and parents might be avoided with open dialogue about how to understand and respect differences in cultural attitudes and values. It gives both parts a wider horizon. Even informal comments to the students may connect their two worlds and contribute to harmonising the educational environment for the students and thereby facilitate their identity development. Cooperation and dialogue between teachers and parents have a triple effect, both for each group and for the immigrant students. Cultural differences are important. Schools represent the students' future where they are introduced to and included in society in a gradual and on-going way. One condition is that they feel they are welcome. When parents do not become acquainted with or misunderstand this society, its values and their children's changing 'world', generational conflicts occur. Therefore, through sharing information about vital cultural values un-clarified and unaccepted differences between parents and school can be avoided, and security can be created. Mutual understanding, information and common acceptance of solutions lead to more coherent education and stable situation for students. Language understanding and cultural acceptance are prerequisites for meaningful dialogue.

In the following, I present The Norwegian Education Act and its regulations, which give the main aim, framework and intentions of the school policy for the youngest generation of migrants and their parents.

\section{What are the opportunities and challenges in official Norwegian policy?}

\section{Opportunities}

According to the Norwegian Act of Education and its regulations, the school must provide education in cooperation with the children's homes (2005). This is not only an obligation for the school, but also for the parents, because 
they have the right to education for their children. The regulations specifically say that at least twice a year there has to be a planned and structured conference with the parents about the status of their student. In addition, there has to be a common meeting each term of the year for all parents of the students at the same level.

The Education Act also prescribes democratic organs, such as a parents' council and a committee for cooperation, where parents are represented. The intention is to give the whole parent group a 'voice', and to share the responsibility for collaboration in the education situation (Education Act, $\$$ 11-1 ff). The parents are obliged to participate in organised meetings and coordinating assemblies, while teachers or the school are responsible for organisation and information. Immigrant parents are not especially mentioned in this connection, but this aspect is underlined and concretised in several other official documents, like the Strategic Plan from the Ministry of Education and Research: 'Equal Education in Practice, 2004-2009', (later 'Strategic Plan'). The plan says that Norway has become a multicultural society, and that it has developed multicultural schools. The latter is described this way: 'The ministry is of the opinion that a multicultural school is characterised by a staff who regard cultural and linguistic diversity among pupils, parents and teachers as the norm, and who base their school development on this' (Strategic Plan, 2004-2009, p. 9).

The necessity of the parents' contribution is emphasised directly: 'The ministry is of the opinion that raising parents' awareness, increasing their involvement and assigning them responsibility are critical factors for the success of the Strategic Plan's overriding goals [...]' (ibid, p. 21).

The latest official document offers a thorough presentation of the total education of students with a minority language, which is to give multi-lingual children, youths and adults the advantage of education (NOU 2010:7, Mangfold og Mestring ${ }^{3}$ [Cultural diversity and Mastering]).

The Education Act gives students who have a mother tongue another than Norwegian a right to special education in Norwegian and even some support in their own language 'as far as possible' and 'when needed' ( $\$ 2-8)$. Thus far, 'needed' has been interpreted by teachers or schools, while the schools or municipality has to evaluate to which degree there are necessary resources and possibilities for support. This ambiguity might lead to opportunities being

3 An NOU is an official study and recommendation to the Ministry usually followed by an agreed White Paper.

This NOU 2010: 7 'Manifold and Mastering' has the subtitle: 'Multilingual children, young and adults in the education system.' Most likely the present NOU will be followed by a White Paper. 
different in different places. Newly arrived migrant parents have a right and a duty to take a language course in Norwegian, and an introduction program about society. Schools have the opportunity to hire interpreters for some meetings, within some economic limits.

All parents, minority and majority, are obliged to cooperate in their children's education at school. This includes participation in meetings where one gets information about the school society and relevant external instances and a possibility to discuss general questions. The conferences between teacher and each parent give the opportunity for mutual information about their child's status and what support parents can give, e.g. in students' homework.

Finally, the Education Act prescribes non-tolerance for bullying and discrimination of racial or ethnic reasons (Education Act, $\$ 9 a$ ).

The overall policy is to qualify both migrant parents and their children to participate in Norwegian society with rights and duties. The minister's preface to the Action Plan begins with: 'Norway intends to be the most inclusive society in the world' (Action Plan, p. 2). With this premise also follows responsibility. Equality in obligations and duties is also part of the official immigration policy expressed in each relevant White Paper and plan document, as is expressed in the Action Plan:

The goal for the Government's social inclusion policy is that each person who lives in Norway shall participate in society and have equal opportunities. The Government's job is to ensure that immigrants are able to contribute their resources in working life and general society as quickly as possible (ibid, 2007, p. 6).

This is a positive and balanced policy, but there are challenges for optimal practice.

\section{Challenges in implementing the policy}

We see four main challenges: the geography of a long country with fjords and mountains, the spread of immigrants, the lack of sufficient multicultural and linguistic competence, and the economy. The country has 429 municipalities of varied areas, natures, economies and competences to care for immigrant children's right to adequate language support, which is a local responsibility. One might find schools with two or three nationalities represented in the classes, but also with $20 \%$ immigrant children. There are more immigrants in towns where they often live in special areas and then with more languages represented. One of the interviewed directors in an ordinary school said they had $48 \%$ minority students, and 30-35 languages represented (Lea, 2009). The average in 
Oslo schools is $39 \%$. There are two schools in Oslo with over $90 \%$ immigrant children and one with $3 \%$, according to the web source (http://www.abcnyheter. no/nyheter/o90822/39-prosent-av-oslos-elever-er-minoriteter).

Evidently this creates great challenges for the directors, the teachers and the municipalities to enhance the acculturation process, to find relevant linguistic competence or economic resources. Resources and competence for translation support are limited and vary throughout the country. As mentioned, it is the schools' or municipalities' responsibility to evaluate the students' need for support and when possible to give this support. There is a newly developed test for language evaluation, but there are challenges. Dyslexia or other language problems in the mother tongue cannot be diagnosed easily.

The aim is that all teachers shall have multicultural competence, as stated in the Knowledge Promotion. Even if they do their best, we see that inservice courses do not reach all. In the autumn of 2011, the first students started with a revised teacher education framework plan in which qualification for the migrant situation in schools were incorporated. The students graduate in 2015. One might say that Norway has started the road to multicultural competence for teachers. How the present challenges might be experienced by parents and teachers is dealt with in the following.

\section{What experiences do teachers encounter?}

It is easy to see that the challenges colour the teachers' perceptions of their situation. The policy gives the general aims, which have to be put into practice in the 429 different municipalities.

They have to allocate the economic resources according to general obligations to support schools, but this also competes with other obligations. Each level of administration has to evaluate how to meet obligations. Even if the framework and intentions are the same in two multicultural schools, the practice might be different in the everyday life with students and parents (Vedøy, 2008). The philosophy of the director will influence the teachers. The framework's plans and regulations give goals and prescriptions that have to be implemented in the teaching. This leaves an openness to choose an effective way to organise the teaching. This 'openness' gives teachers power to define, for example, what is most important in a certain class, as Cummins says, (1986/2001, p. 653). If teachers might doubt their own multicultural competence in meeting many nationalities, one can try to get a supplementary course, another might do as the Catalan Professor X. B. Costa suggests, and start discussions between students and teacher or between students from different cultures to compare 
similar features or possible differences in culture and language (Costa, 1997). Well-handled challenges might lead to new solutions, but teachers have to find learn put these solutions into practice.

The teachers' practice is varied. In the interviews with directors and teachers of some primary schools, their experience showed both possibilities and limitations (Lea, 2007, 2009). Two schools were especially responsible for receiving newcomers, still in mixed groups. One was defined as a 'focus school', responsible for giving advice to others. ${ }^{4}$ One ordinary school had a high percentage of migrant students. This shows that the schools had to take care of the multicultural aspect on somehow different conditions. Each school was a small society with its own atmosphere, dependent on factors like size, priorities, persons and economy. As Vedøy showed, the schools had their own rules and practice for behaviour (2008). It was impossible to say that one was better than the other without further observations.

Regarding the question of bullying or discrimination, we know that it can be a rather hidden issue. In her doctoral work, Fandrem found that there are differences in reasons for bullying between Norwegian and immigrant youngsters. The immigrant youngsters wanted to get into a group to be included, while the Norwegian ones wanted to show power (Fandrem, 2009). Insight in reasons for bullying might make it easier to handle. Communication between minority and majority students is vulnerable, but so too is the communication between school and parents.

This is documented in Elsa Westergård's $\mathrm{PhD}$ thesis, in which she presents what she calls 'parental disillusionment with school' (2010). Her conclusion is that there are difficulties in communication when a teacher does not recognise the problem for students or parents. For example, if it agreed that there is a bullying problem, parents and teachers might disagree about the cause of or the solution to the bullying. Elements in the teachers' workload, professional security or cultural background can hinder professional receptivity in a situation or their ability to make adjustments. Unclear expectations regarding the roles of the teacher or parent might disturb the communication between the two parties when cooperating, e.g. the earlier referred example of cultural based disagreement about the basis for authority. The teachers' challenge is to analyse the situation, clarify their own possible prejudices and role expectations, to be

4 Focus school. A National Centre for multicultural Education gives service to a multicultural school (and kindergarten) in every county. The school has the obligation to develop their competency in multicultural competence and be a model for other schools and to create a network. 
open and to be clear. With less mutual knowledge of ways of living and thinking and or language differences, the possibilities for misunderstanding are greater. Without cultural knowledge, one might be tolerant, but in an indifferent way, without respectful understanding.

The conference with each parent couple gives the mutual opportunity to ask and answer questions. Every week, the teacher sends a plan for the school activities next week, which gives parents an opportunity to support the child and be oriented about the content in education. Parents might always ask questions when needed, but the conference is obligatory. The conference time is 20 minutes, twice a school year, at school, where teachers say they need more time to talk about the students' social and subject activities, find out what kind of resource the parents are, and discuss ways of doing things. In plans sent home, they include (for example) 'word banks' to discuss and learn, relevant for a subject. According to one teacher, the conference time is not sufficient for everybody, so she added unpaid time to the conference (Lea, 2007, p. 17). Sometimes, parents might ask if their child behaves well or does what is expected of them. It seems, however, as if the information mostly goes from teacher to parent, which might signal parents' authority respect or experience from a culture where parents were never asked, or (as the teacher said) too little time to the conferences. One school had limited interpreter support for four years per class for conferences (Lea, 2007). This varies according to need and economy, and the teacher has no influence on the funds available.

The meetings for all parents have to be relevant for both the majority and the minority. It is not an easy task, because of the diverse situation in different schools. There is a national committee for parents in elementary school (Foreldreutvalget for grunnskolen (FUG)) who has developed material for cooperation between school and parents, including migrant parents: 2010, Broer mellom hjem og skole, [Bridges between home and schools]. The web-pages are open for ideas and pamphlets, some translated to many different languages (www.fug.no).

The situation of planning arrangements together is an open occasion. Language is then crucial. The impression is that the conferences have the priority use of translators. The meetings give parents an opportunity to become acquainted with each other. Thus, both teachers and school directors try to find ways, for example by letting more experienced parents translate in their language for small groups in the common meetings. The subjects presented are varied. It might be discussions around topics from school policy, rules and culture, information from institutions the school cooperate, including child welfare, police and health security (Hauge, 2004). If they choose presentations of their own specialities and competences, one of the directors emphasised that 
these presentations from immigrants easily become marked by a 'kind of show', which he warns against. It can result in stereotypic pictures, exotic for the majority group. Telling about the culture of today from different countries important to themselves, leads to more understanding. In this way, all parents may become resources and enhance the acculturation (Lea, 2009).

The informants affirm that the language capacity or the availability of translators is decisive in meaningful communication with the migrant parent, both in conferences and meetings (Lea, 2007). Restricted opportunities for language interpretation are particularly important to address. Difficulties in language capability may also have something to do with the fact emphasised by Høigård (2010) that even understanding an everyday language, is (also for parents) not sufficient to understand a more advanced language. The meetings, therefore, have to be planned carefully in order to reach everyone. ${ }^{5}$ This will become easier when all migrants participate in the newly introduced obligatory course in Norwegian language. This shows that many challenges in mutual understanding of each other in the parents' group, in meetings, in conferences or in dialogues are dependent on the language capability and translation. The teacher's communicative competence and understanding is exceedingly important in direct dialogues.

\section{Concluding remarks}

Cooperation between parents and school is exceedingly important for the students, the migrant parents, their family life and the teachers. Immigrant parents have to raise their children considering their future in a new society, and want the best qualifications for their children. In addition, they have to take to care of the family life, where values and traditions are often different from the style in Norwegian families.

Norwegian policy has an 'equal education for all' perspective for all students in the education system, described systematically in official documents. We find the obligation to cooperate for parents and school in the Norwegian Education Act and its regulations. The equality aspect is dealt with in the extra language support for migrant students in their mother tongue or in Norwegian language when needed. There is also added support to translation in the cooperation with immigrant parents in conferences or meetings.

Research has shown that this cooperation is important for all parts.

5 In the appendix, I present an overview for shared duties and responsibilities in a school. This 'service declaration' is a result of the parents' council's cooperation in this school, where migrant parents naturally are included. 
Immigrant families live in an acculturation process to become acquainted to a new society with a different language and culture. Research also shows that cooperation between school and parents has favourable effects. Cultural values of the other part might be strange, not really understandable or even threatening. Through information and dialogues, one might arrive at mutual understanding and practicable solutions. This contributes to the parents' understanding of the school policy and how they can support the education. When realising how crucial language competence is for the students' understanding in the teaching situation, it can be supported by parents, school or experts in different ways. This gives a more coherent education situation for the students, favourable to the learning process. Furthermore, the cooperation might prevent intergenerational conflicts in the migrant family, because parents understand more of what a future in the new society means.

Mutual communication and cooperation between migrant and majority parents in conferences and common meetings can clarify cultural differences and give information about the students' education situation. This openness enhances the acculturation process for all parts and supports the education. Cooperation enhances teachers' multicultural and professional competence, gives security to parents and a coherent education to students.

As said, the intentions of the Norwegian policy are to include immigrants, welcome them and give equal education to all. Still there are challenges in the implementation process of the official policy which have to be mentioned. The challenges point towards future improvements. One needs resources and competence at all levels, including school practice. All municipalities and all schools all over the country have to provide language support 'when needed', and this requires competence, good tools, expertise and economy. The reality is that municipalities differ greatly in size, in geography and also in different language competence or money available. Even in central areas, the need of mother tongue support and translations are still greater than the available financial means and available language competence, because of the many nations represented in some schools. Schools might also have teachers without necessary information about how to evaluate language capacity or to handle cultural differences. The multicultural competence in teaching and cooperation still has to become more professional. The newest national idea is to develop the language competence in immigrant pupils is by giving migrant children under the school age an obligatory start in kindergarten. This does not solve all the challenges of immigrant students above that age.

If the earlier-mentioned Pisa tests indicate the ability of migrant youth to participate on equal footing in the society, there is still a way to go. Nevertheless, the intentions in the Norwegian education policy point to the Child 
Convention principles of mutual respect for parents, language and culture. It seems as if we need both aspects. In this connection, I have not analysed the selection of the content in different subjects in school, which also is an important factor that has to be meaningful to the students. The dynamism in acculturation and education processes in both minority and majority groups have so many facets and factors that it is impossible to say 'Do this and the result will be that'.

Every teacher's communicative skills, language learning, cultural knowledge and understanding ease the teaching in the schools and the cooperation where both minority and majority parents are important resources. Research has documented that the cooperation between teachers and parents is of fundamental significance for creating coherence in the education of the students, which is also important for the family and school. There is more awareness of the complexity today than a few years ago. There are new challenges for all involved and responsible levels of education from official policy to the single teacher. The challenges are found in the equality perspective of policy compared to the reality, in allocation of money, school practice and also in developing linguistic and multicultural competence in the new generation of teachers.

\section{References}

Education Act (2005). Oslo: Ministry of Education and Research.

Ministry of Labour and Social inclusion (2007). Action Plan for Integration and Social Inclusion of the Immigrant Population and Goals for Social Inclusion. Oslo: Government Adm. Services.

Ministry of Education and Research (2007). Equal Education in Practice: Strategy for better learning and greater participation by language minorities in education (2004-2009). Oslo. Retreived form www. publikasjoner.dep.no.

Ministry of Education and Research (2008). Kunnskapsløftet (Knowledge Promotion). Oslo.

[Ministry] (2010). Mangfold og mestring. Flerspråklige barn, unge og voksne i opploeringssystemet [Manifold and mastery. Multilingual children, young and adults in the education system] (NOU: 2010-7). Oslo: The service-centre of the Ministry. Retrieved from http://www.regjeringen.no/pages/10797590/PDFS/ NOU201020100007000DDDPDFS.pdf.

Barry, B. (2001). Culture and equality: An egalitarian critique of multiculturalism. Cambridge: Polity. Brochmann, G., \& Kjelstadli, K. (2008). A history of Immigration: The Case of Norway, 900-200o. Oslo: Universitetsforlaget.

Costa, X. B. (1997). Intercultural education and teacher training. In Woodrow ( Ed.), Intercultural education; theories, policies and practice (pp.183-201). Aldershot: Ashgate.

Cummins, J. (2001). Empowering minority students: A framework for intervention. Harvard Educational Review, 71(4), 649-675.

Fandrem, H. (2009). Psychological and sociocultural adaption among adolescents in Norway with 
immigrant backgrounds: a study of depressive symptoms and bullying. no 68. Stavanger: University of Stavanger, Faculty of Arts and Education.

Ferreira, M. M., \& Cardoso, A. J. (2004). Second Generation Cape Verdean Immigrants in Portugal: Problems of School Integration. AEMI, pp.79-85.

Høigård, A. (2006). Barns språkutvikling: muntlig og skriftlig [Children’s language development, oral and written]. Oslo: Universitetsforlaget.

Hauge, A.-M. (2007). Den felleskulturelle skolen [The commoncultural school], 2nd ed. Oslo:

Universitetsforlaget.

Lea, M. (2007). Interaction between immigrant parents and teachers for the school children. Final research paper. Stavanger: Faculty of arts and education, University in Stavanger.

Lea, M. (2008). The Cape Verdean slum areas in Portugal. Integration or segregation. How does the school prepare the young Cape Verdean Immigrant generation to integration in the Portuguese society? Final research paper. Stavanger: Faculty of arts and education, University in Stavanger.

Lea, M. (2009). Migrant pupils and equal opportunities?: How does Norwegian teacher education qualify to teaching in multicultural schools? [Master's thesis]. Stavanger: University of Stavanger. Retrieved from http://brage.bibsys.no/uis/bitstream/URN:NBN:no; bibsys_brage_10201/1/Lea\%2c\%20Martha.pdf. Nieto, S. (2000). Bringing Bilingual Education out of the Basement. In Z. F. Beykont, Lifting every voice: pedagogy and politics of bilingualism (pp.187-199). Cambridge, Mass.: Harvard Education Publishing Group.

Nieto, S. (2010). Language, culture and teaching ( $2^{\text {nd }}$ ed.). New York: Routledge.

Parekh, B. (2008). A New Politics of Identity (1 ed.) (pp.187-199). Hampshire: Palgrave McMillan.

Pisa 2009 results. (2010). Overcoming social background - Vol. II. OECD.

Portes, A., \& Rumbaut, R. G. (2001). Legacies: the story of the immigrant second generation. Berkeley: Russell Sage Foundation.

Robins, K. (2003/1996). Interrupting identities: Turkey/Europe in Hall and Gay ed. In Questions of cultural Identity, (ch.5, pp. 61-87). London: Sage Publications.

Simon, B. (2004). Identity in modern society a social psychological perspective. Blackwell Publishing. Sjögren, A. (2000). Föräldrar på främmande mark [Parents in strange fields]. In KRUT, nr.1/2, (pp. 11-17). United Nations, Convention on Rights of the Child (1989).

Vedøy, G. (2008). „En elev er en elev“" "barn er barn“ og „folk er folk“. Ledelse i flerkulturelle skoler [Pupils are pupils, children are children, people are people. Leadership in multicultural schools], $\mathrm{PhD}$. University in Oslo.

Westergård, E. (2010). Parental disillusionment with school. Prevalence, correlates, development and prevention, $\mathrm{Ph} \mathrm{D}$. University in Stavanger.

\section{Internet source}

http://www.abcnyheter.no/nyheter/o90822/39-prosent-av-oslos-elever-er-minoriteter. http://www.fug.no. 


\section{Appendix}

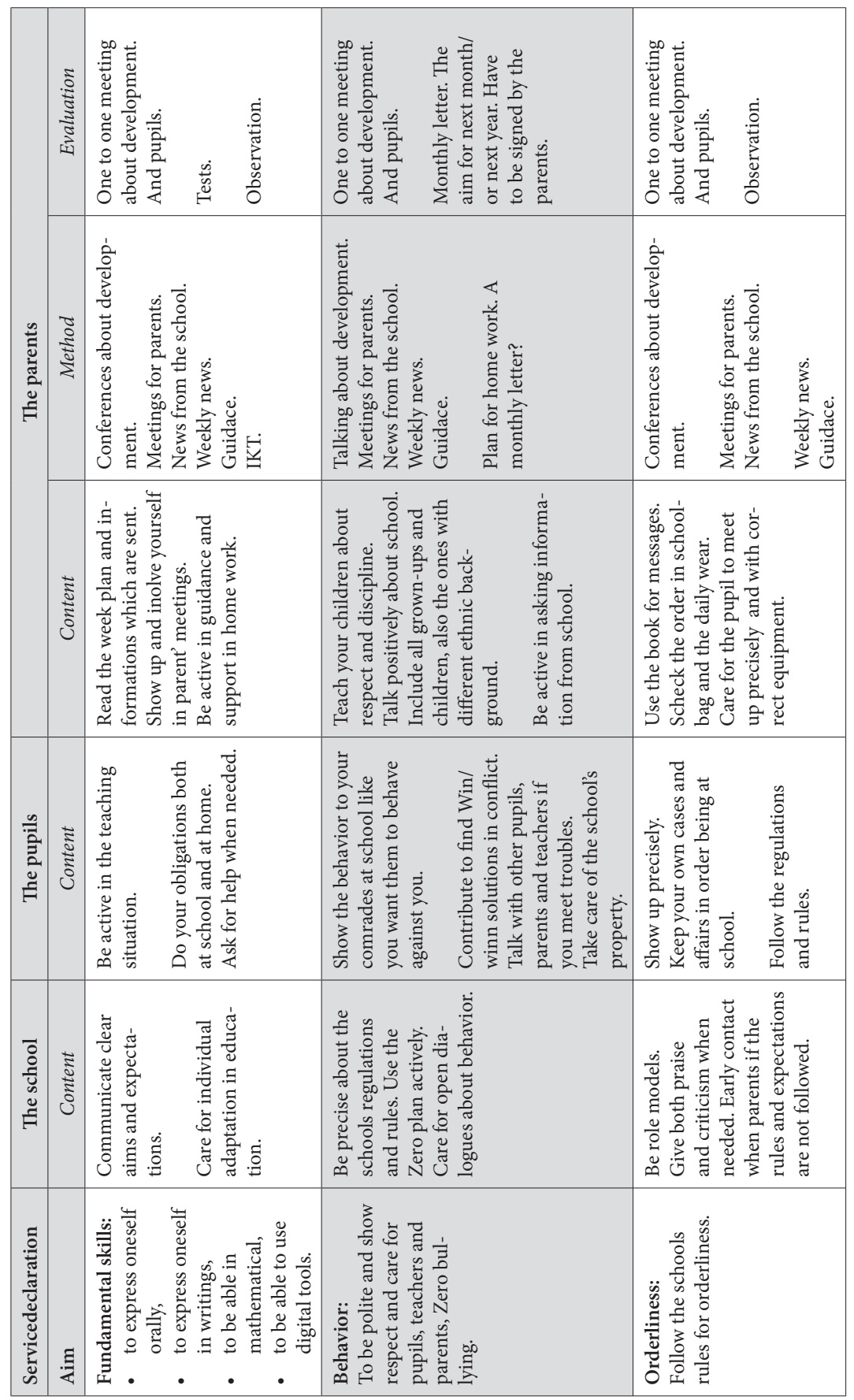




\section{Biographical note}

MARTHA LEA is an Associate professor em. in University in Stavanger, Norway. She has: a Master degree in pedagogy: Master thesis about possible profit of organising pre-school teacher education in projects; Associate professor degree, related to research of the qualification of pre-school teacher students in models organised as distant education in Norway, Iceland and Scotland; Master degree in "Migration and Intercultural Relations": Master Thesis How Norwegian Teacher Education qualify to teaching in multicultural schools?. She is teaching at all levels of education, mainly the university. Participates in international projects and presentations in conferences. 